\title{
SATB2 Gene
}

National Cancer Institute

\section{Source}

National Cancer Institute. SATB2 Gene. NCI Thesaurus. Code C75580.

This gene plays roles in apoptosis and development. 